\title{
BINDING OF URANYL IONS BY WATER-INSOLUBLE POLYMERS CONTAINING MULTILIGAND GROUPS
}

\author{
BERNABÉ L. RIVAS, ${ }^{1 *}$ IVÁN M. PERIČ ${ }^{2}$ SANDRA VILLEGAS, ${ }^{1}$ BEATRIZ RUF, ${ }^{1}$ \\ ${ }^{1}$ Polymer Department, Faculty of Chemical Sciences, University of Concepción, Concepción, Chile \\ ${ }^{2}$ Analytical and Inorganic Chemistry Department, Faculty of Chemical Sciences, University of Concepción, Concepción, Chile
}

(Received: 26 September 2007 - Accepted: 20 December 2007)

\begin{abstract}
The crosslinked resins poly(N-(3-dimethylamino)propylmethacrylamide) P(NDAPA), poly((3-dimethylamino)propylacrylate)P(DAPA), poly(4acryloylmorpholine-co-acrylic acid) P(AMo-AA), poly(N-(3-dimethylamino)propylmethacrylamide-co-4-vinyl pyridine) P(NDAPA-VPy) and poly((3-dimethyl amino)propylacrylate-co-acrylic acid) P(DAPA-AA), poly(N-(3-dimethylamino)propylmethacrylamide-co-acrylic acid) P(NDAPA-AA) were obtained by radical polymerization. These resins were completely insoluble in water. The uptake metal ion properties were studied by batch equilibrium procedure for copper(II) and uranyl ions.
\end{abstract}

Keywords: resin; radical polymerization; metal ions; polymer-metal complexes

\section{INTRODUCTION}

Environmental conservation is of increasing social and economic importance. A particular pollution problem is the contamination of water by metal ions. The recovery of uranium from contaminated water of flooded mines $\left(01-15 \mathrm{mg} \mathrm{u} / \mathrm{m}^{3}\right)$ also presents a very important problem to be solved. Hence, the design of effective host molecules for uranyl ions is related with the economic importance of selective extraction of uranium from water. ${ }^{1-3}$

The process using adsorbents is thought to be the most effective method for recovery of uranium because of the high selectivity for uranium, the case of handling, the safety to the environment, etc. Examples of well-studied polymer ligands of uranyl ions are: carboxylate such as EDTA analogues, phenol, $\beta$ ketone, ammonium, sulfonic acid, and amidoxime. ${ }^{4-24}$

Various separation/pre-concentration techniques have been used for uranyl ion such as liquid extraction and solid phase extraction using cation exchangers, chemically modified or impregnated silica, active carbon, and Amberlite XAD resins. ${ }^{25-32}$

Other technique for the preparation of solid phase sorbent is the imprinting technique that could be used for selective separation and pre-concentration of trace metal ions as uranium. ${ }^{33-34}$

Synthetic polymers can modify the properties of functional groups attached to the backbone and improve the effectiveness of various molecular functions. In addition, modification of the microenvironments of synthetic polymers often improves the effectiveness of the functional groups. Thus, the chemical modification of the macromolecular backbones can improve the uranyl-binding properties.

The aim of the current manuscript is the synthesis of resins containing several functional groups to remove efficiently copper and uranyl ions at different $\mathrm{pH}$.

\section{EXPERIMENTAL}

\section{Reagents}

Acrylic acid (AA, Merck), 4-Acryloylmorpholine (AMo, 97\% Aldrich), 4-vinyl pyridine (VPy, 95\% Aldrich), 1,4-divinylbenzene (DVB, Fluka), N-(3-dimethylamino)propylmethacrylamide (NDAPA, Aldrich), 3-dimeth ylamino)propylacrylate (DAPA, Aldrich) were purified by distillation. 2,2'Azoisobutyronitrile (AIBN, Merck) was recrystallized from methanol, N,N'methylene-bis-acrylamide (MBA, 99\% Aldrich) and ammonium persulfate (AP, 95\% Aldrich) were used without further purification.

The analytical grade, copper(II) nitrate, uranyl acetate, nitric acid, perchloric acid, sodium hydroxide and sodium carbonate were purchased from Merck.

Synthesis of the resins P(NDAPA), P(DAPA), P(AMo-AA), P(NDAPAAA), P(NDAPA-VPy), and P(DAPA-AA)

The resins P(NDAPA), P(DAPA), P(AMo-AA), P(NDAPA-AA), $\mathrm{P}(\mathrm{NDAPA}-\mathrm{VPy})$, and $\mathrm{P}$ (DAPA-AA) were synthesized by radical polymerization by mixing the corresponding reagents in a polymerization flask as follows:

P(NDAPA): NDAPA $(0.0552 \mathrm{~mole}, 10 \mathrm{~mL}), \mathrm{MBA}(0.00228 \mathrm{~mole}, 0.3552$ $\mathrm{g})$ and $\mathrm{AP}(0.000299 \mathrm{~mole}, 0.0684 \mathrm{~g})$ in $10 \mathrm{~mL}$ of water. Yield $=91.0 \%$.

P(DAPA): DAPA (0.0552 mole, $10 \mathrm{~mL})$, MBA $(0.00232 \mathrm{~mole}, 0.3621 \mathrm{~g})$ and AP $(0.000285$ mole, $0.0651 \mathrm{~g})$. Yield $=82.0 \%$.
P(AMo-AA): AMo (0.04 mole, $5 \mathrm{~mL})$, AA (0.043 mole, $3 \mathrm{~mL})$, DVB $(0.0035$ mole, $0.5 \mathrm{~mL})$ and AIBN (0.00039 mole, $0.0651 \mathrm{~g})$ (Merck) in $8 \mathrm{~mL}$ of dry toluene. Yield $=95.0 \%$.

P(NDAPA-AA): NDAPA (0.0276 mole, $5 \mathrm{~mL})$, AA ( $0.029 \mathrm{~mole}, 2 \mathrm{~mL})$, MBA $(0.0021$ mole, $0.3461 \mathrm{~g})$ and AP $(0.00027$ mole, $0.0605 \mathrm{~g})$ in $7 \mathrm{~mL}$ of water. Yield $=97.0 \%$.

P(NDAPA-VPy): NDAPA (0.0276 mole, $5 \mathrm{~mL})$, VPy $(0.0278$ mole, 3 $\mathrm{mL})$, MBA $(0.0022$ mole, $0.3450 \mathrm{~g})$ and $\mathrm{AP}(0.00031 \mathrm{~mole}, 0.0697 \mathrm{~g})$ in $8 \mathrm{~mL}$ of water. Yield $=87.0 \%$.

P(DAPA-AA): DAPA (0.0295 mols, $5 \mathrm{~mL})$, AA $(0.0292$ mole, $2 \mathrm{~mL})$, MBA (0.0023 mole, $0.3659 \mathrm{~g})$ and AP (0.00027 mole, $0.0618 \mathrm{~g})$ in $7 \mathrm{~mL}$ of water. Yield $=99.0 \%$.

The polymerization mixtures were kept under nitrogen at $70^{\circ} \mathrm{C}$ for $8 \mathrm{~h}$ (see Scheme 1). Then methanol was added and the resin was removed from the flask, filtered and washed with abundant water. The resin was dried under vacuum at $40^{\circ} \mathrm{C}$ and then milled and sized by screening. The fraction with mesh size in the range of $250-500 \mathrm{~mm}$ was chosen.

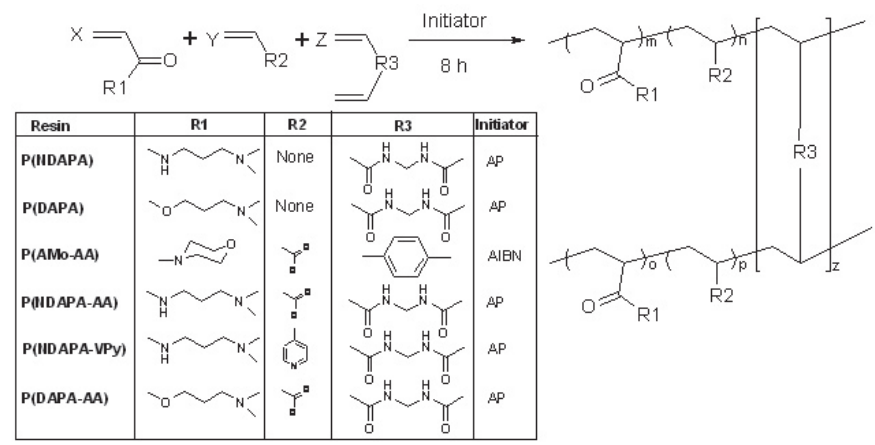

Scheme 1. Synthesis and structure of the resins

Resin - metal ion uptake

The effect of the $p \mathrm{H}$ on the metal ion retention properties was studied by batch equilibrium procedure. These batch metal uptake experiments were carried out using the standard metal salts $\mathrm{Cu}\left(\mathrm{NO}_{3}\right)_{2}$ and $\mathrm{UO}_{2}\left(\mathrm{CH}_{3} \mathrm{COO}\right)_{2}$ at $p \mathrm{H}$ range $1-5$. All experiments were carried out in flasks placed on a shaker at $20^{\circ} \mathrm{C}$. The retention ability for $\mathrm{Cu}(\mathrm{II})$ and $\mathrm{U}(\mathrm{VI})$, under noncompetitive and competitive conditions was determined as a function of the $p \mathrm{H}$. Batches of $50.0 \mathrm{mg}$ of resin were used, together with a mixture of $5.00 \mathrm{~mL}$ of metal ion(s) solution. Under noncompetitive conditions the resin/metal ion ratio (in mol) is 20:1.0. Under competitive conditions, solutions were prepared as before but considering the sum total mmole of the metal ions involved to keep constant the resin/metal ion ratio. After a shaking time of $1 \mathrm{~h}$ at a desired temperature, each sample was filtered and washed with deionized water at the corresponding $p \mathrm{H}$. Filtrate was collected into calibrated $100-\mathrm{mL}$ volumetric flask and made up to volume. In all cases, copper(II) was determined by atomic absorption spectrometry (AAS) and uranium(VI) colorimetrically. ${ }^{24}$

Temperature effect on $\mathrm{Cu}(\mathrm{II})$ and $\mathrm{U}(\mathrm{VI})$ ion retention was performed with 
all the resins at $20,25,30,35$ and $40^{\circ} \mathrm{C}$ under shaking for $1 \mathrm{~h}$.

To obtain the maximum adsorption capacity for the metal ions, batches of $50.0 \mathrm{mg}$ resin were used together with a mixture of $25.00 \mathrm{~mL}$ of $1.0 \mathrm{~g} / \mathrm{L}$ metal ion solution. After a shaking time of $1 \mathrm{~h}$ at $20^{\circ} \mathrm{C}$, each sample was filtered. Then, the batches were reconstituted by adding $25.00 \mathrm{~mL}$ of fresh metal ion solution. The process was repeated three times. The last filtration step was followed by a washing step with water at the corresponding $p \mathrm{H}$. Filtrate was collected into calibrated $100 \mathrm{~mL}$ volumetric flask and made up to volume.

\section{RESULTS AND DISCUSSION}

Synthesis and characterization of the resins

Six water-insoluble resins were synthesized by radical polymerization. Resins were characterized by FT-IR spectroscopy. Table I shows the most characteristic absorption bands which confirm the polymerization process. Resin compositions were determined from their FT-IR spectra by comparison of the areas corresponding to each monomer.

Table I. Most FT-IR characteristic absorption bands of the resins.

\begin{tabular}{|c|c|c|c|c|c|}
\hline Resin & Charact & tic absorpt & on bands & $\left.\mathrm{cm}^{-1}\right)$ of & e resins \\
\hline P(NDAPA) & $\begin{array}{l}\mathrm{C}=\mathrm{O} \\
1642\end{array}$ & $\begin{array}{l}\mathrm{C}-\mathrm{H} \\
2943\end{array}$ & $\begin{array}{l}\mathrm{N}-\mathrm{H} \\
3436\end{array}$ & $\begin{array}{c}\mathrm{CH}_{3}-\mathrm{N} \\
2864\end{array}$ & - \\
\hline P(DAPA) & $\begin{array}{l}\mathrm{C}=\mathrm{O} \\
1728\end{array}$ & $\begin{array}{c}\mathrm{CH}_{3}-\mathrm{N} \\
2955\end{array}$ & $\begin{array}{c}\text { C-N } 1 \\
1394\end{array}$ & $\begin{array}{l}\mathrm{C}-\mathrm{O} \\
1256\end{array}$ & $\begin{array}{c}\mathrm{O}=\mathrm{C}- \\
\mathrm{CH}_{2} \\
1631\end{array}$ \\
\hline P(AMo-AA) & $\begin{array}{l}\mathrm{C}=\mathrm{O} \\
1730\end{array}$ & $\begin{array}{l}\mathrm{C}=\mathrm{O} \\
1629\end{array}$ & $\begin{array}{c}\mathrm{O}-\mathrm{CH}_{2} \\
2862\end{array}$ & $\begin{array}{c}\text { C-N } 1 \\
1362\end{array}$ & $\begin{array}{l}\mathrm{C}-\mathrm{O} \\
1258\end{array}$ \\
\hline $\begin{array}{l}\text { P(NDAPA- } \\
\text { AA) }\end{array}$ & $\begin{array}{l}\mathrm{C}=\mathrm{O} \\
1634\end{array}$ & $\begin{array}{c}\mathrm{CH}_{3}-\mathrm{N} \\
2949\end{array}$ & $\begin{array}{l}\text { C-N } \\
1382\end{array}$ & $\begin{array}{l}\mathrm{C}-\mathrm{O} \\
1282\end{array}$ & $\begin{array}{l}\mathrm{N}-\mathrm{H} \\
3442\end{array}$ \\
\hline $\begin{array}{l}\text { P(NDAPA- } \\
\text { VPy)* }\end{array}$ & $\begin{array}{l}\mathrm{C}=\mathrm{O} \\
1644\end{array}$ & $\begin{array}{c}\text { Stretching } \\
\text { of Py ring } \\
1943\end{array}$ & $\begin{array}{l}\mathrm{CH}_{3}-\mathrm{CN} \\
2861\end{array}$ & $\begin{array}{l}\mathrm{C}=\mathrm{N} \\
1551\end{array}$ & $\begin{array}{l}\mathrm{C}=\mathrm{C} \\
1598\end{array}$ \\
\hline P(DAPA-AA) & $\begin{array}{l}\mathrm{C}=\mathrm{O} \\
1710\end{array}$ & $\begin{array}{l}\mathrm{C}=\mathrm{O} \\
1644\end{array}$ & $\begin{array}{l}\mathrm{C}-\mathrm{O} \\
1225\end{array}$ & $\begin{array}{c}\mathrm{CH}_{3}-\mathrm{N} \\
2934\end{array}$ & $\begin{array}{c}\mathrm{O}-\mathrm{CH}_{2} \\
2667\end{array}$ \\
\hline
\end{tabular}

* From reference ${ }^{35}$

The thermal study under dynamic conditions demonstrates that resins $\mathrm{P}(\mathrm{NDAPA}), \mathrm{P}(\mathrm{NDAPA}-\mathrm{VPy})$, and P(DAPA-AA) were very stable up to $200^{\circ} \mathrm{C}$, whereas $\mathrm{P}(\mathrm{DAPA}), \mathrm{P}(\mathrm{AMo}-\mathrm{AA})$ and $\mathrm{P}(\mathrm{NDAPA}-\mathrm{AA})$ were more unstable showing a thermal loss up to $14.5 \%$ at the same temperature. At a higher temperature, the weight loss increases remarkably and comparatively for the resin $\mathrm{P}(\mathrm{AMo}-\mathrm{AA})$ at $300^{\circ} \mathrm{C}$ and $400^{\circ} \mathrm{C}$. These results are summarized in Table II.

Table II. Weight-loss of the resin at different temperatures. Heating rate: $10^{\circ} \mathrm{C} \mathrm{min}^{-1}$. atmosphere: nitrogen.

\begin{tabular}{|l|c|c|c|c|c|}
\hline \multirow{2}{*}{ Resin } & \multicolumn{5}{|c|}{ Weight-loss (\%) at different temperatures $\left({ }^{\circ} \mathbf{C}\right)$} \\
\cline { 2 - 6 } & $\mathbf{1 0 0}$ & $\mathbf{2 0 0}$ & $\mathbf{3 0 0}$ & $\mathbf{4 0 0}$ & $\mathbf{5 0 0}$ \\
\hline P(NDAPA) & 0 & 2.5 & 14.6 & 44.5 & 82.1 \\
\hline P(DAPA) & 0.1 & 6.2 & 29.2 & 57.3 & 89.2 \\
\hline P(AMo-AA) & 0.9 & 8.0 & 34.1 & 64.5 & 82.7 \\
\hline P(NDAPA-AA) & 0 & 14.5 & 25.2 & 54.3 & 95.5 \\
\hline $\begin{array}{l}\text { P(NDAPA- } \\
\text { VPy)* }\end{array}$ & 1.7 & 3.1 & 6.2 & 46.7 & 93.9 \\
\hline P(DAPA-AA) & 0.3 & 4.2 & 15.9 & 39.2 & 74.0 \\
\hline
\end{tabular}

* From reference. ${ }^{25}$
Metal ion adsorption studies

Effect of the $\mathbf{p H}$

This study was carried out basically to compare the affinity and selectivity of the resins toward copper(II) and uranium(VI). $p \mathrm{H}$ influences the polymer surface chemistry and the solution chemistry of the metal ions under study. It is known that variation of the $p \mathrm{H}$ can affect the surface charge of the adsorbent, and the degree of ionization and speciation of adsorbate. ${ }^{36} \mathrm{Hence}$, the adsorption dependence on resins at different $p \mathrm{H}$ for the metal ions was determined (see Figures 1-3).

The contact time used was $1 \mathrm{~h}$ insofar as all the metal ions achieve the equilibrium close to $30 \mathrm{~min}$ which is considered too fast as the reactions occur in heterogeneous media.

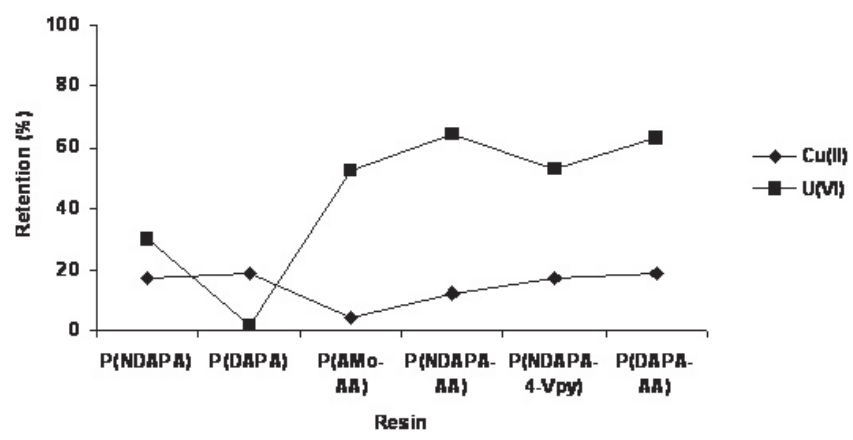

This Figure 1. Retention (\%) at $p \mathrm{H} 1$ for the resins. Initial amount of each metal ion: $0.20 \mathrm{mmol} / \mathrm{g}$ dry resin.

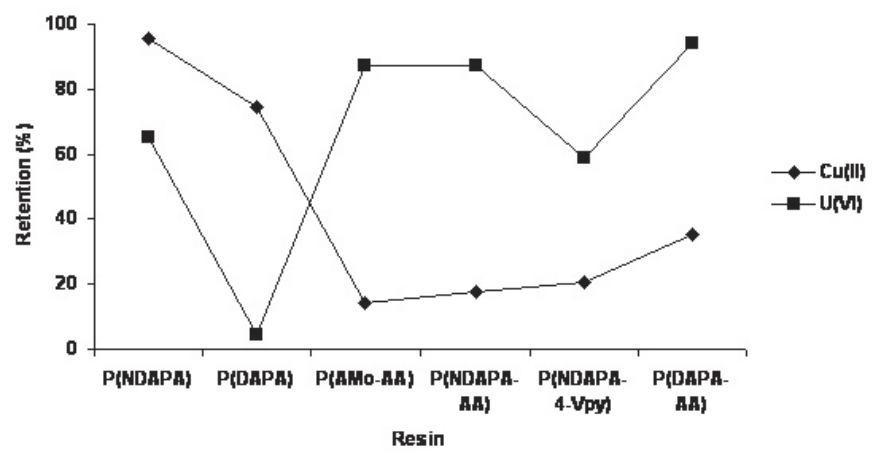

Figure 2. Retention (\%) at $p \mathrm{H} 3$ for the resins. Initial amount of each metal ion: $0.20 \mathrm{mmol} / \mathrm{g}$ dry resin.

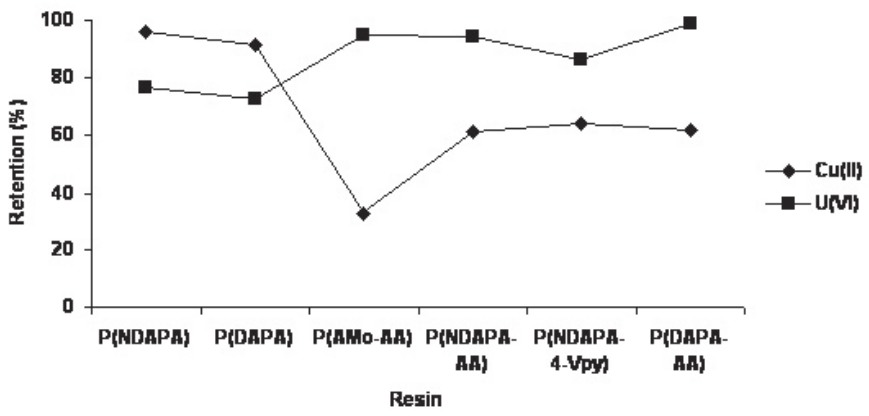

Figure 3. Retention (\%) at $p \mathrm{H} 5$ for resins. Initial amount of each metal ion: $0.20 \mathrm{mmol} / \mathrm{g}$ dry resin. 
short adsorption equilibrium time take place probably due to a high complexation rate (i.e. high affinity), between $\mathrm{Cu}(\mathrm{II})$ and $\mathrm{U}(\mathrm{VI})$ ions and the functional group anchored in the resin structure.

The influence of $p \mathrm{H}$ on the adsorption of $\mathrm{Cu}(\mathrm{II})$ ions can be explained on the basis of the well known electrostatic interaction model. ${ }^{37}$ As the $p \mathrm{H}$ decreases, the surface of the resin enhances its positive character. At very low $p \mathrm{H}$ values copper(II) ion is positive charged and its adsorption is not favored at all. Competition between $\mathrm{H}^{+}$and metal cations minimizes the extent of the metal ion adsorption indeed. As the $p \mathrm{H}$ increases, the adsorbent surface enhances its negative character and therefore, the adsorption of copper(II) becomes favorable. These studies were carried out only up to $p \mathrm{H} 5$ because above this value the precipitation of $\mathrm{Cu}(\mathrm{OH})_{2}$ starts to occur.

The high retention of $\mathrm{U}(\mathrm{VI})$ observed at low $p \mathrm{H}$ can be explained by considering that the nitrogen atom of the pyridine moiety is protonated at low $p \mathrm{H}$, particularly at the $p \mathrm{H}$ range $1-2$, forming $-\mathrm{NH}^{+} \mathrm{A}^{-}$- groups. These protonated groups have a nitrogen atom without a free-electron pair capable of forming coordination bonds with the $\mathrm{UO}_{2}{ }^{2+}$ ions. Therefore, it could be possible to suggest that an ion-exchange process could be involved in the retention of $\mathrm{UO}_{2}{ }^{2+}$ ions. In this case, it would exchange the anion by $\left[\mathrm{UO}_{2}\left(\mathrm{NO}_{3}\right)_{3}\right]^{-38,39}$ Particularly, $\mathrm{P}(\mathrm{AMo}-\mathrm{AA})$ shows a good selectivity for $\mathrm{U}(\mathrm{VI})$ at $p \mathrm{H} 3$ and $p \mathrm{H}$ 5 toward $\mathrm{Cu}(\mathrm{II})$. On the other hand, $\mathrm{P}(\mathrm{DAPA})$ shows a higher selectivity for $\mathrm{Cu}(\mathrm{II})$ toward $\mathrm{U}(\mathrm{VI})$ at $p \mathrm{H} 3$.

\section{Maximum retention capacity (MRC)}

In order to explore the applications of the adsorbents, it is very important to know the adsorption capacity of resins for the metal ions studied. Results are summarized in Figure 4. Examination of these results shows that resins $\mathrm{P}(\mathrm{NDAPA})$ and $\mathrm{P}(\mathrm{DAPA})$ have a higher MRC for $\mathrm{Cu}(\mathrm{II})$ toward U(VI) whereas $\mathrm{P}(\mathrm{AMo}-\mathrm{AA}), \mathrm{P}(\mathrm{NDAPA}-\mathrm{AA}), \mathrm{P}(\mathrm{NDAPA}-\mathrm{VPy})$, and P(DAPA-AA) have the greatest MRC values for $\mathrm{U}(\mathrm{VI})$ toward $\mathrm{Cu}(\mathrm{II})$. Consequently, when pyridine or carboxylic moieties are present the retention of $\mathrm{Cu}(\mathrm{II})$ decreases. In this context the resin $\mathrm{P}(\mathrm{AMo}-\mathrm{AA})$ shows a remarkable selectivity for $\mathrm{U}(\mathrm{VI})$ toward $\mathrm{Cu}(\mathrm{II})$, at optimum $\mathrm{pH}$ within experimental error.
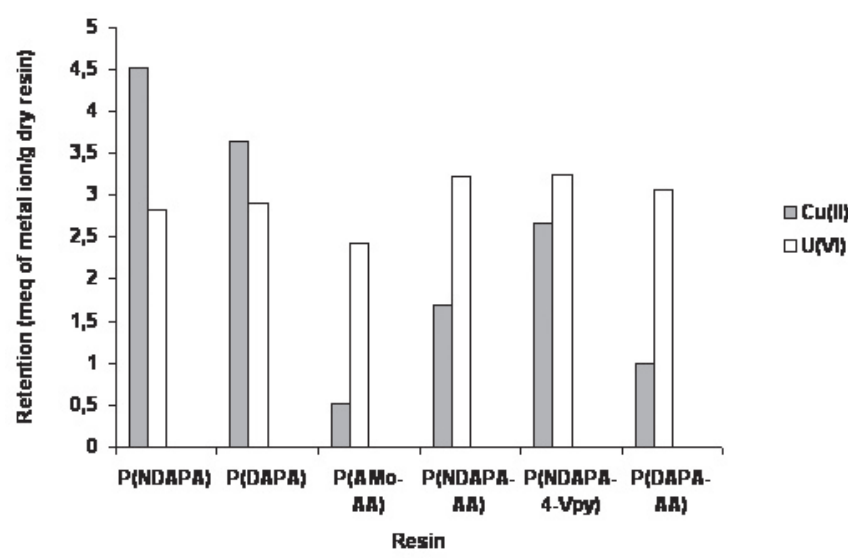

口U(M)

Figure 4. Maximum retention capacity, MRC, (meq of metal ion/g dry resin) of resins at $\mathrm{pH} 5$

\section{Effect of the temperature solution}

In consideration to the results of the effect of $p \mathrm{H}$ on the retention, the effect of the temperature solution was studied for the retention of $\mathrm{Cu}(\mathrm{II})$ and $\mathrm{U}(\mathrm{VI})$ at $p \mathrm{H} 5$.

A general behavior was found, retention of both cations decrease as the temperature increases, from $20^{\circ} \mathrm{C}$ to $40{ }^{\circ} \mathrm{C}$ (data not shown). Hence, knowing that the adsorption reaction is exothermic, higher temperatures could induce an increasing decomposition of the chelate or the ion exchanger group, which can explain the drop of the adsorption rate. The optimal solution temperature was $20{ }^{\circ} \mathrm{C}$ under the range of temperatures assayed. An example of this behavior is shown for $\mathrm{P}(\mathrm{NDAPA})$ in Figure 5.

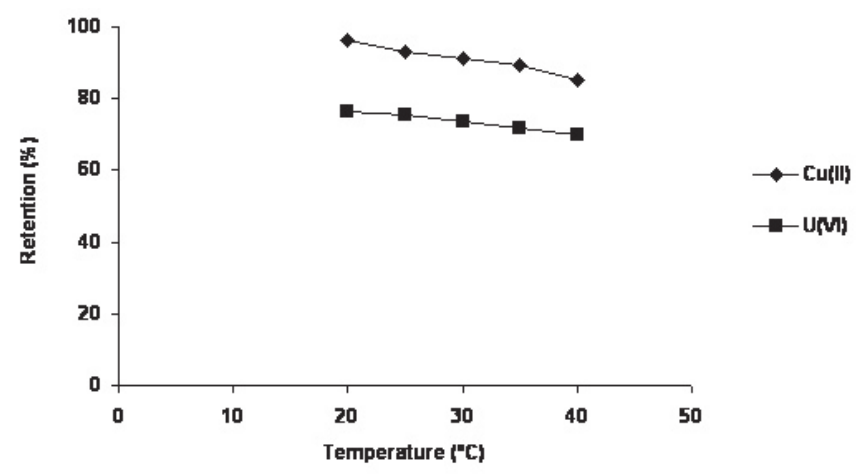

Figure 5. Effect of the temperature on the metal ion retention, $\mathrm{R}(\%)(\mathrm{mmol}$ of metal ion $/ \mathrm{g}$ dry resin) of $\mathrm{P}(\mathrm{NDAPA})$ at $p \mathrm{H} 5$.

\section{Elution behavior}

Regeneration of resins is likely to be an important factor when improving process economics. In metal remediation processes, metal ions should be easily eluted from loaded resins under suitable conditions. Therefore, elution was evaluated by performing it in a batch experimental set-up. Various factors are mostly involved in the metal ion elution, such as the extent of hydration of the metal ions and adsorbent microstructure. Nevertheless, a key factor appears to be the binding strength. When $\mathrm{HClO}_{4}$ or $\mathrm{HNO}_{3}$ are used as the elution media, the coordination spheres of the chelated metal ions are disrupted and, subsequently, these ions are released from the resin. In this study the elution time was $1 \mathrm{~h}$. These elution studies suggest the possibility to elute selectively $\mathrm{Cu}(\mathrm{II})$ from U(VI) when resin P(NDAPA) is used (see Figures 6 and 7). The ability to reuse the resins was carried for the resins $\mathrm{P}(\mathrm{DAPA})$ as well as $\mathrm{P}(\mathrm{AMo}-$ AA) (see Figures 8 and 9). For the resin P(DAPA) as well as P(AMo-AA) the adsorption behavior of U(VI) is almost stable for four cycles of use. The adsorption capacity of the recycled adsorbent can be maintained at a greater than $80 \%$ level at the fourth cycle.

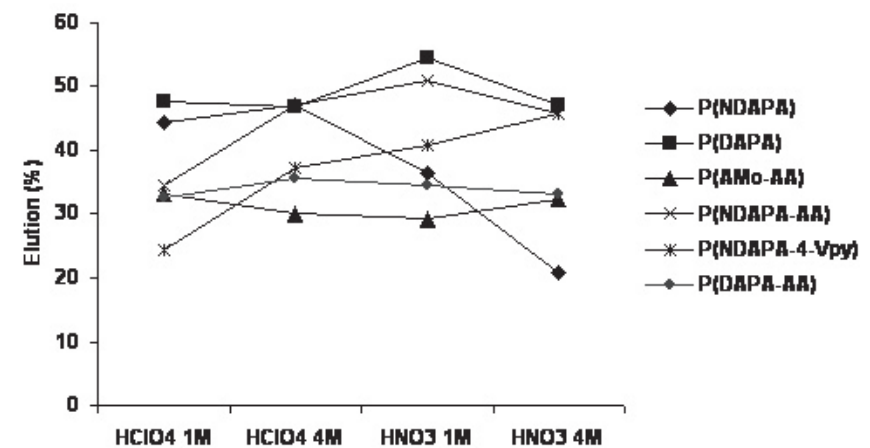

Figure 6. Elution (\%) of $\mathrm{Cu}(\mathrm{II}) \mathrm{v} / \mathrm{s}$ eluents from the loaded resins at $p \mathrm{H}$

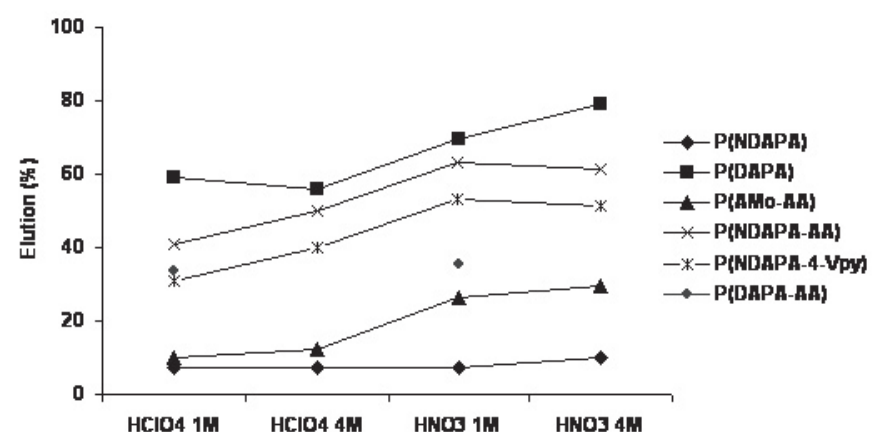

Figure 7. Elution (\%) of $\mathrm{U}(\mathrm{VI}) \mathrm{v} / \mathrm{s}$ eluents from the loaded resins at $p \mathrm{H}$ 
For resin P(DAPA-AA) additional elution assays were performed with 1 and $4 \mathrm{M} \mathrm{Na}_{2} \mathrm{CO}_{3}$ with a recovery of $81.9 \%$ and $90.0 \%$ respectively.

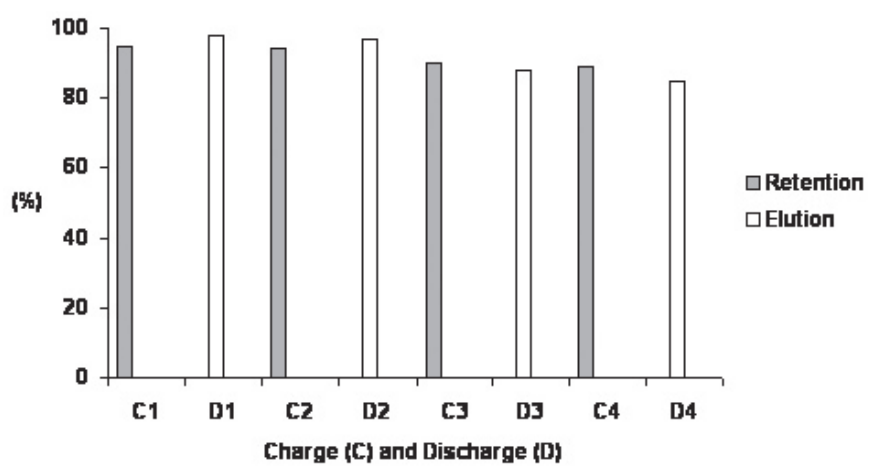

Figure 8. Charge-discharge cycles of U(VI) from $\mathrm{P}(\mathrm{DAPA})$ by $4 \mathrm{M} \mathrm{HNO}_{3}$. $0.1627 \mathrm{mmol}$ of $\mathrm{U}(\mathrm{VI})$ with $0.1 \mathrm{~g}$ dry resin are contacted at $p \mathrm{H} 5$.

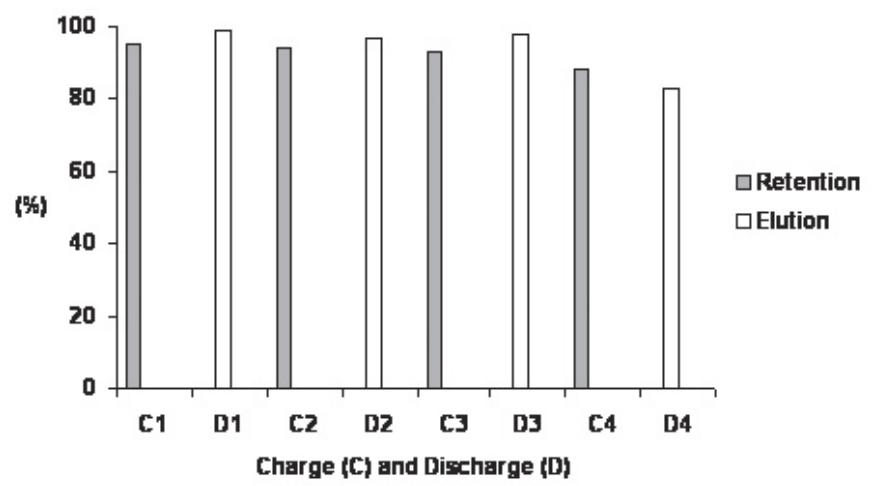

Figure 9. Charge-discharge cycles of U(VI) from $\mathrm{P}(\mathrm{AMo}-\mathrm{AA})$ by $4 \mathrm{M}$ $\mathrm{HNO}_{3} .0 .1040$ mmole of $\mathrm{U}(\mathrm{VI})$ with $0.1 \mathrm{~g}$ dry resin are contacted at $p \mathrm{H} 5$.

The metal ion retention under competitive conditions was studied by considering a $\mathrm{Cu}(\mathrm{II})-\mathrm{U}(\mathrm{VI})$ mixture. As example, results are shown in Figure 9 for resin P(DAPA-AA) which shows a higher selectivity for U(VI). A similar result was found by resin $\mathrm{P}(\mathrm{AMo}-\mathrm{AA})$ (data not shown).

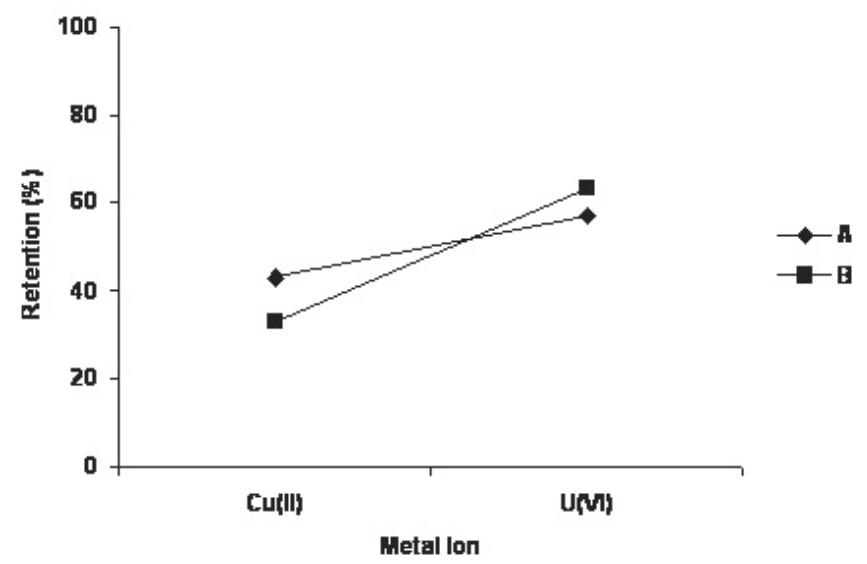

Figure 10. Metal ion retention behavior from an aqueous solution mixture (\%) of the resin P(DAPA-AA). 0.00462 mmole of each ion and 0.00924 mmole (total content of metal ions) at $p \mathrm{H} \mathrm{5.} \mathrm{A} \mathrm{=} \mathrm{Metal} \mathrm{ion} \mathrm{retention} \mathrm{assuming} \mathrm{the} \mathrm{total}$ metal ions content in mixture. $\mathrm{B}=$ Metal ion retention assuming the initial content of metal.

\section{CONCLUSIONS}

The crosslinked P(NDAPA), P(DAPA), P(AMo-AA), P(NDAPA-AA), $\mathrm{P}(\mathrm{NDAPA}-\mathrm{VPy})$, and $\mathrm{P}(\mathrm{DAPA}-\mathrm{AA})$ resins were synthesized by solution radical polymerization. Among these resins those which contain pyridine and carboxylic acid groups showed a higher affinity in the removal of U(VI) ions from an aqueous solutions below $p \mathrm{H} 3$.

\section{ACKNOWLEDGEMENTS}

The authors thank FONDECYT (Grant No 1070542), CIPA, and the Dirección de Investigación, Universidad de Concepción the partial financial support

\section{REFERENCES}

1. I. Tabushi, I, Y. Kobuke, T. Nishiya, Nature, 280, 665 (1979)

2. R.V. Davies, J. Kennedy, R.W. Mcllroy, R. Spence, Nature, 203, 1110 (1964)

3. S. Shinkai, H. Koreishi, K. Ueda, T. Arimura, O. Manabe,. J Am Chem Soc, 109, 637 (1987).

4. J. Xu, K.N. Raymond, Inorg Chem, 38, 308 (1999).

5. H.S. Park, J.H. Cho, J. Suh, J Polym Sci A: Polym Chem, 35, 2935 (1997).

6. G..H. Carey, A.E. Martel, J Am Chem Soc 90, 32 (1968).

7. N. Kabay, H. Egawa, Sep Sci Technol 29, 135 (1994).

8. J.J.R.F da Silva, M.F.S. Simoes, J Inorg Chem 32, 1313 (1970).

9. H. Güler, N. Sahiner, G.A. Aycik, O. Güven, J Appl Polym Sci 66, 2475 (1977).

10. K. Sugasaka, S. Katoh, N. Takai, H. Takahashi, Y. Umezawa, Sep Sci Technol 16, 971 (1981).

11. H.J. Schenk, L. Astheimer, E.G. Witte, K. Schwochau, Sep Sci Technol 17, $1293(1982)$.

12. H. Omichi, A. Kataki, T. Sugo, J. Okamoto, Sep Sci Technol 20, 163 (1985).

13. D. Leroy, L. Martinot, M. Debecker, D. Strivay, G. Weber, C. Jérôme, R. Jérôme,. J Appl Polym Sci 77, 1230 (2000).

14. B.L. Rivas, H.A Maturana, S. Villegas, J Appl Polym Sci 77, 1994 (2000).

15. B.L. Rivas, H.A. Maturana, R. Catalán, I.M. Perich, J Appl Polym Sci 38 , 801 (1989).

16. B.L. Rivas, H.A. Maturana, E.D. Pereira, Angew Macromol Chem 220, 61 (1994).

17. B.L. Rivas, H.A. Maturana, I.M. Perich, E. Pereira, Polym Bull 37, 191 (1996).

18. J. Bartulín, H. Maturana, B.L. Rivas, I.M. Perich, Polym Bull 12, 189 (1984).

19. J. Bartulín, B.L. Rivas, M.L. Ramos, Polym Bull 112, 393 (1984).

20. B.L. Rivas, H.A. Maturana, I.M. Perich, U. Angne, Polym Bull 14, 239 (1985).

21. B.L. Rivas, H.A. Maturana, R.E. Catalán, I.M. Perich, U. Angne, Polym Bull 19, 609 (1988).

22. B.L. Rivas, K.E. Geckeler, Adv Polym Sci 102, 171 (1992).

23. Synthesis, Properties and Applications and Analytical Properties B.L. Rivas, in The Polymeric Material Encyclopedia. J. Salamone (Ed.) CRC Press, Boca Raton, Florida, USA, 6, 4137-4143 (1996).

24. J. A. Pérez-Bustamante, F. Palomares-Delgado, Analyst 96, 407 (1971).

25. E.A. Huff, Chromatogr 27, 229 (1967).

26. P. Schmitt, P.D. Beer, M.G.B. Drew, P.D. Sheen, Tetrahedron Lett 39 , $6383(1998)$.

27. H. Onishi, K. Sekini, Talanta, 19, 473 (1972).

28. R.T. Gerontopulos, L. Rigali, P.G. Barbano, Radiochim Acta, 4, 75 (1966).

29. M.A. Maheswari, M.S. Subramanian, React Funct Polym 51, 101 (2002).

30. M. Merdivan, M.Z. Díaz, C. Hamamci, Talanta 55, 639 (2001).

31. V.K. Jian, S.S. Sait, P. Shrivastav, Y.K. Agrawal, Sep Sci Technol. 33, $1803(1998)$

32. T.P. Rao, P. Metilda, G.M. Gladis, Talanta, 68, 1047 (2006).

33. J.M. Gladis, T.P Rao, Microchim Acta 146, 251 (2004).

34. T.P. Rao, R. Kala, S. Daniel, Anal Chim Acta, 578, 105 (2006).

35. B.L. Rivas, S. Villegas, B. Ruf, I.M. Perič, J Chil Chem Soc 52, 1088 (2007).

36. H.A. Elliot, C.P. Huang, Water Res, 15, 481 (1981).

37. J.I. Bullok, D.G. Tuck, J Chem Soc, 1877 (1965).

38. M. Bühl, R. Diss, G. Winff, Inorg Chem, 46, 5196 (2007).

39. S. De Houwer, J. Görler-Warland, Alloys Compd, 323-324, 683 (2001). 